University of Nebraska - Lincoln

DigitalCommons@University of Nebraska - Lincoln

Faculty Papers and Publications in Animal

Science

Animal Science Department

October 1988

\title{
EFFECT OF SEX RATIO OF THE BIRTH LITTER ON SUBSEQUENT REPRODUCTIVE PERFORMANCE OF GILTS
}

\author{
W. R. Lamberson \\ University of Missouri, Columbia \\ R. M. Blair \\ University of Missouri, Columbia \\ K. A. Rohde Parfet \\ University of Missouri, Columbia \\ B. N. Day \\ University of Missouri, Columbia \\ R. K. Johnson \\ University of Nebraska-Lincoln, rjohnson5@unl.edu
}

Follow this and additional works at: https://digitalcommons.unl.edu/animalscifacpub

Part of the Animal Sciences Commons

Lamberson, W. R.; Blair, R. M.; Rohde Parfet, K. A.; Day, B. N.; and Johnson, R. K., "EFFECT OF SEX RATIO OF THE BIRTH LITTER ON SUBSEQUENT REPRODUCTIVE PERFORMANCE OF GILTS" (1988). Faculty Papers and Publications in Animal Science. 47.

https://digitalcommons.unl.edu/animalscifacpub/47

This Article is brought to you for free and open access by the Animal Science Department at DigitalCommons@University of Nebraska - Lincoln. It has been accepted for inclusion in Faculty Papers and Publications in Animal Science by an authorized administrator of DigitalCommons@University of Nebraska - Lincoln. 


\title{
EFFECT OF SEX RATIO OF THE BIRTH LITTER \\ ON SUBSEQUENT REPRODUCTIVE PERFORMANCE OF GILTS ${ }^{1}$
}

\author{
W. R. Lamberson ${ }^{2}$, R. M. Blair ${ }^{2}$, K. A. Rohde Parfet ${ }^{2}$, B. N. Day ${ }^{2}$ and R. K. Johnson ${ }^{3}$ \\ University of Missouri ${ }^{2}$, Columbia 65211 and \\ University of Nebraska ${ }^{3}$, Lincoln 68583
}

\begin{abstract}
Records on age at puberty from 1,555 gilts and total number of pigs born in litters of 1,187 gilts from the Nebraska gene pool population were used to evaluate the effects of uterine environment on subsequent reproductive performance. Independent variables were line, year, line $X$ year, proportion of males in the birth litter (sex ratio), number born in the birth litter (fraternity size) and sex ratio $X$ fraternity size. Sex ratio, fraternity size and their interaction influenced age at puberty $(P<.01)$ but not number born $(P>.2)$. Partial regression coefficients indicated that age at puberty tended to decrease as sex ratio increased, particularly in small litters. Although the regression coefficients were relatively large, sex ratio, fraternity size and their interaction accounted for only $1.3 \%$ of the variation in age at puberty within line $X$ year subclass. These results offer little encouragement for the use of sex ratio as a phenotypic selection criterion for improvement of reproductive performance in gilts. Results suggest that female swine are similar to rodents in response to uterine environmental effects.
\end{abstract}

(Key Words: Pigs, Puberty, Litter Size, Prenatal Period, Siblings, Sex Ratio.)

Introduction
Reproductive performance is of great importance in the efficiency of swine production (Tess et al., 1983). Heritabilities of reproductive traits tend to be low to moderate, .10 for litter size and .31 for age at first estrus (Young et al., 1978). Low heritabilities suggest that factors other than additive genetic effects, which may or may not be subject to control by producers, account for substantial amounts of variation in these traits.

Reproductive traits may be influenced by the endocrine environment to which gilts are exposed in utero. It has been shown (vomSaal, 1981) that age at first estrus and length of reproductive lifetime of female rodents were affected by their in utero position with respect to the sex of their adjacent littermates. Ford et al. (1980) reported that testes of the fetal pig

\footnotetext{
${ }^{1}$ Contribution from the Missouri Agric. Exp. Sta., journal series no. 10354. This study was supported in part by U.S. Dept. of Agric. grant no. 85-CRCR-11874.

${ }^{2}$ Dept, of Anim. Sci.

${ }^{3}$ Dept. of Anim. Sci.

Recejved July 16, 1987.

Accepted October 13, 1987.
}

secrete testosterone during a period critical in the differentiation of internal and external genitalia. The proportion of gilts exhibiting estrus by $250 \mathrm{~d}$ of age and weight of reproductive organs were significantly reduced in gilts born to females treated with testosterone propionate on d 30, 50 or 70 of gestation (Elsaesser and Parvizi, 1979).

The probability that a male fetus occupies a specified position adjacent to a given fetus in utero is equal to the sex ratio of the litter. Thus, it is hypothesized that gilts born in litters with high sex ratios or a large proportion of males have increased likelihood of being exposed to elevated concentrations of testosterone prenatally compared with gilts born in litters with low sex ratios. The objective of this study was to evaluate the effect of sex ratio of birth litter and its interaction with litter size on reproductive traits in gilts.

\section{Materials and Methods}

Data used for this study were collected at the University of Nebraska Field Laboratory at Mead, Nebraska. Genetic composition of the gene pool population was described by Cunningham and Zimmerman (1975). These data were collected during 1979 to 1986 on four 
TABLE 1. DESCRIPTIVE STATISTICS FOR AGE AT PUBERTY AND NUMBER BORN

\begin{tabular}{lccc}
\hline Trait & No. & $\overline{\mathrm{X}}$ & SD $^{\mathrm{a}}$ \\
\hline Age at puberty & 1,555 & 169.6 & 26.4 \\
Number born & 1,187 & 9.5 & 2.9 \\
Sex ratiob & 601 & .50 & .16 \\
Fraternity sizeb & 601 & 9.8 & 2.6 \\
Sex ratioc $^{\mathrm{a}}$ & 540 & .49 & .15 \\
Fraternity sizec & 540 & 9.9 & 2.8 \\
\hline
\end{tabular}

${ }^{\mathrm{a}} \mathrm{SD}=$ standard deviation.

${ }^{b}$ Litters contributing gilts used in age at puberty analyses.

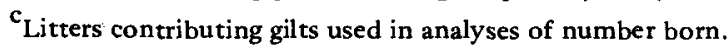

lines of swine involved in an experiment in which selection was applied to decrease age at puberty in one line, to increase litter size in one line and at random in two lines.

Pigs were maintained in confinement. Only gilts were farrowed. Piglets were fostered within line with the intention that no gilt rear more than 10. Weaning was at $28 \mathrm{~d}$. Pigs were confined in the nursery in pens of 25 until $56 \mathrm{~d}$ of age. From $56 \mathrm{~d}$ to breeding age, gilts were housed in single-sex groups of 10 in modified open-front buildings.

Traits studied were number born (NB), defined as the number of fully formed piglets, and age at first estrus (AP). Evaluation of AP was begun when the oldest pig in a pen was no older than $135 \mathrm{~d}$ of age. Once each day gilts were moved to a common heat check pen and exposed to a mature intact boar for $20 \mathrm{~min}$. A gilt was considered to be in estrus if she stood solidly to a mount by the boar. Estrus detection was continued until all gilts were found in estrus or the youngest gilt not found in estrus was $250 \mathrm{~d}$ of age. No more than $3 \%$ of gilts in any year failed to express estrus. Records from gilts that failed to express estrus were excluded from the analysis. Generation interval was $1 \mathrm{yr}$. Farrowing occurred during late winter each year.

Data were analyzed using ordinary leastsquares analysis of variance. A model including the discrete effects of line, year, the interaction of line $x$ year and the continuous effects of fraternity size (FRAT), defined as the number of pigs in the gilts' birth litter, sex ratio (SR), defined as the proportion of the gilts' birth litter that was male, and the interaction between FRAT and SR was fitted to each depen-

TABLE 2. ANALYSES OF VARIANCE FOR AGE AT PUBERTY AND NUMBER BORN

\begin{tabular}{|c|c|c|c|c|}
\hline \multirow[b]{2}{*}{ Source of variance } & \multicolumn{2}{|c|}{ Age at puberty } & \multicolumn{2}{|c|}{ Number born } \\
\hline & $\mathrm{df}^{\mathrm{a}}$ & $\begin{array}{l}\text { Mean } \\
\text { square }\end{array}$ & df & $\begin{array}{l}\text { Mean } \\
\text { square }\end{array}$ \\
\hline Line & 3 & $10,400^{* *}$ & 3 & $142.5^{* *}$ \\
\hline Year & 6 & $4,337 * *$ & 5 & $32.4^{*}$ \\
\hline Line $\times$ year & 7 & $1,609^{*}$ & 13 & 15.6 \\
\hline Fraternity size & 1 & $4,383^{* *}$ & 1 & .2 \\
\hline Sex ratio & 1 & $4,281 * *$ & 1 & 2.8 \\
\hline Fratemity size $\times$ sex ratio & 1 & $3,886^{*}$ & 1 & .05 \\
\hline Error & 1,535 & 621 & 1,162 & 7.3 \\
\hline
\end{tabular}


dent variable. Sire effects were not included in the model because the potential application of results from this study should be in selection of replacement gilts applied within contemporary groups but across sire groups.

\section{Results and Discussion}

Age at puberty was measured on a total of 1,555 gilts. Descriptive statistics for the trait are presented in Table 1 . Results of the analysis of AP are presented in Table 2. Each independent variable represented a highly significant source of variation. Partial regression coefficients for the effects of FRAT, SR and their interaction were $-2.2 \pm .8 \mathrm{~d} / \mathrm{pig}$ in the birth litter, $-43.1 \pm 16.4 \mathrm{~d} /$ unit, and $4.2 \pm 1.7 \mathrm{~d} / \mathrm{pig}$ $X$ unit, respectively. Expressed as standard partials, regression coefficients were $.43 \pm .15$ for FRAT, $.48 \pm .19$ for SR and $.61 \pm .25$ for their interaction. Predicted AP for nine combinations of FRAT and SR are presented in Table 3. Although the effects of SR, FRAT and their interaction were highly significant, they together accounted for only $1.3 \%$ of the variation in AP after variation due to line, year and line $x$ year was removed, with each effect contributing to an approximately equal extent.

As the proportion of males increased in litters, AP declined. The magnitude of decline was greater in small litters. These results seem contrary to expectations based on studies by Elsaesser and Parvizi (1979). In that study the proportion of gilts attaining puberty by $250 \mathrm{~d}$ of age was significantly reduced compared with controls ( 8.3 vs $45.5 \%)$ if their dams had been exposed to testosterone propionate between $\mathrm{d}$ 30 and 70 of gestation. In a study using mice, vomSaal and Bronson (1978) categorized females as developing in utero between two females $(O M)$ or between two males $(2 M)$. When these females were individually placed in cages next to a male, $2 \mathrm{M}$ females were older at puberty than $O M$ females. However, when females were grouped in cages next to a male, $2 M$ females were younger at puberty than $O M$ females. The latter situation may be more similar to the present study because gilts were housed in single-sex groups after d 56 .

Descriptive statistics for NB are presented in Table 1. Partial regressions of NB on FRAT, SR and their interaction were $.04 \pm .10 \mathrm{pig} / \mathrm{pig}$ in the birth litter, $.03 \pm 1.8 \mathrm{pig} /$ unit, and $.01 \pm .18$ $\mathrm{pig} / \mathrm{pig} \times$ unir, respectively. None of these regression coefficients approached statistical significance. These results are contrary to those
TABLE 3. PREDICTED AGES AT PUBERTY FOR COMBINATIONS OF BIRTH LITTER FRATERNITY SIZES AND SEX RATIOS

\begin{tabular}{lccc}
\hline & \multicolumn{3}{c}{ Sex ratio } \\
\cline { 2 - 4 } Fraternity size & .3 & .5 & .7 \\
\hline 7 & 189 & 177 & 166 \\
10 & 180 & 171 & 162 \\
13 & 170 & 164 & 158 \\
\hline
\end{tabular}

reported by Edgerton and Cromwell (1986). In that study, low SR sows had larger litters than high SR sows $(10.2$ vs $9.2 ; P<.05)$; however, data from only six pairs of non-littermate sib sows were used.

Studies with rodents, reviewed by vomSaal (1981) did not reveal intrauterine position effects on NB. Effects on number surviving were dependent on the environment in which the litter was reared. In an environment in which there was competition among litters, females exposed to male sibs in utero expressed an advantage in number weaned.

Sex ratio of the birth litter significantly affected AP but not NB. Despite significant effects of SR on AP and a relatively large regression coefficient, the low coefficient of determination offers little encouragement for SR to be used as a criterion in the selection of replacement gilts. Results from this study suggest that female swine may be similar to rodents in their response to uterine environmental effects.

\section{Literature Cited}

Edgerton, L. A. and G. L. Cromwell. 1986. Sex of siblings may influence reproductive performance of sows. J. Anim. Sci. 63 (Suppl. 1):365.

Elsaesser, F. and N. Parvizi. 1979. Estrogen feedback in the pig: Sexual differentiation and the effect of prenatal testosterone treatment. Biol. Reprod. 20:1187.

Ford, J. J., R. K. Christenson and R. R. Maurer. 1980. Serum testosterone concentrations in embryonic and fetal pigs during sexual differentiation. Biol. Reprod. 23:583.

Tess, M. W., G. L. Bennett and G. E. Dickerson. 1983. Simulation of genetic changes in life cycle efficiency of pork production. 2. Effects of components on efficiency. J. Anim. Sci. 56:354.

vomSaal, F. 1981. Variation in phenotype due to random intrauterine positioning of male and female fetuses in rodents. J. Reprod. Fertil. 
$62: 633$.

vomSaal, F. S., and F. H. Bronson. 1978. In utero proximity of female mouse fetuses to males: Effect on reproductive performance during later life. Biol. Reprod. 19:842.

Young, L. G., R. A. Pumfrey, P. J. Cunningham and D. R. Zimmerman. 1978. Heritabilities and genetic and phenotypic correlations for prebreeding traits, reproductive traits and principal components. J. Anim. Sci. 46:937.

Zimmerman, D. R. and P. J. Cunningham. 1975. Selection for ovulation rate in swine: Population, procedures and ovulation response. J. Anim. Sci. 40:61. 